Communication

\title{
Bioactive Diterpenoids from Clerodendrum kiangsiense
}

\author{
Mingfeng Xu, Shengjia Wang, Ouya Jia, Qin Zhu and Lu'e Shi *
}

Received: 24 December 2015 ; Accepted: 8 January 2016 ; Published: 15 January 2016

Academic Editor: Derek J. McPhee

Zhejiang Provincial Key Laboratory for Genetic Improvement and Quality Control of Medicinal Plants, Hangzhou Normal University, Hangzhou 310036, China; zjxmf@163.com (M.X.); shinya33@163.com (S.W.); prospectjoy@sina.com (O.J.); zhuqin@hznu.edu.cn (Q.Z.)

* Correspondence: shilue@126.com; Tel.: +86-571-2886-1007

Abstract: A new abeo-abietane diterpenoid, 12-methoxy-6,11,14,16-tetrahydroxy-17(15 $\rightarrow 16)$-abeo5,8,11,13-abietatetraen-3,7-dione (8), was isolated from the hydroalcoholic extract of the herb of Clerodendrum kiangsiense along with seven known diterpenoids (1-7). Their structures were identified on the basis of spectroscopic analyses including two-dimensional NMR and comparison with literature data. All of these compounds were evaluated for their cytotoxic activities against the growth of human cancer cells lines HL-60, SMMC-7721, A-549 and MCF-7 by the MTT assay. The results showed that cryptojaponol (4), fortunin E (6) and 8 exhibited significant cytotoxicity against four human cancer cell lines.

Keywords: Clerodendrum kiangsiense; abeo-abietane diterpenoid; cytotoxicity

\section{Introduction}

Abietane diterpenoids are a class of tricyclic diterpenoids, and have been isolated from plant species from the taxonomic families Verbenaceae, Lamiaceae, Taxaceae [1-4]. Clerodendrum is a genus of about 400 species in the family Verbenaceae, which mainly grows in tropical and warm temperate zones including Africa and Southern Asia. A few species are found in South America, Northern Australia and Eastern Asia [5]. Preparations of the leaves, branches and stems of Clerodendrum have been used in folk medicine to treat different diseases such as cancer, catarrhal affections of the lungs, fever, inflammation, skin diseases and asthma $[6,7]$.

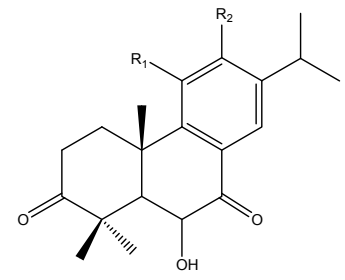

$1 \mathrm{R}_{1}=\mathrm{H}, \mathrm{R}_{2}=\mathrm{OH}$ $2 \mathrm{R}_{1}=\mathrm{OH}, \mathrm{R}_{2}=\mathrm{OCH}_{3}$

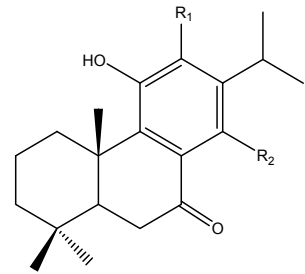

$3 \mathrm{R}_{1}=\mathrm{OH}, \mathrm{R}_{2}=\mathrm{H}$ $4 \mathrm{R}_{1}=\mathrm{OCH}_{3}, \mathrm{R}_{2}=\mathrm{H}$ $5 \mathrm{R}_{1}=\mathrm{H}, \mathrm{R}_{2}=\mathrm{OH}$<smiles>CC(C)c1cc2c(cc1O)[C@@]1(C)CCC[C@](C)(CO)C1C(O)C2=O</smiles>

6<smiles>COc1c(O)c2c(c(O)c1C[C@H](O)F)C(=O)C(O)=C1C(C)(C)C(=O)CC[C@]12C</smiles>

Figure 1. Compounds isolated from Clerodendrum kiangsiense. 
Phytochemical investigations on Clerodendrum species revealed various diterpenoids in the plants, which showed antibacterial and cytotoxic activities [8,9]. However, the phytochemical composition of the stems and roots of $C$. kiangsiense have not been full characterized. As a part of our ongoing effort to discover potential anticancer compounds from Chinese medicinal plants, the stems of C. kiangsiense, collected in Jiangxi Province, were investigated systematically. This has led to the isolation and structure elucidation of a new abeo-abietane diterpenoid (8) and seven known substances (1-7) (Figure 1). Compounds 1-8 were evaluated for their cytotoxicity against four cancer cell lines.

\section{Results and Discussion}

Compound 8 was isolated as colorless crystals from the EtOAc fraction of the ethanol extract of $C$. kiangsiense, it was assigned the molecular formula $\mathrm{C}_{21} \mathrm{H}_{26} \mathrm{O}_{7}$ (9 degrees of unsaturation) by HRESIMS $(\mathrm{m} / z \text { 389.1597 [M - H] }]^{-}$, calcd. for $\mathrm{C}_{21} \mathrm{H}_{25} \mathrm{O}_{7}{ }^{-}$, 389.1599). The absorption bands in the UV spectrum $(238,285,336,381 \mathrm{~nm})$ exhibited the presence of a benzene and a ketone. In the IR spectrum, two carbonyl signals were observed at 1660 and $1715 \mathrm{~cm}^{-1}$ in addition to the absorption peak at $3405 \mathrm{~cm}^{-1}$ for the hydroxyl moiety.

The ${ }^{1} \mathrm{H}$ - and ${ }^{13} \mathrm{C}-\mathrm{NMR}$ spectroscopic data (Table 1 ) indicated the presence of four methyls $\left[\delta_{\mathrm{H}}\right.$ $1.28(3 \mathrm{H}, \mathrm{d}, J=5.5 \mathrm{~Hz}, \mathrm{H}-17), \delta_{\mathrm{H}} 1.53(3 \mathrm{H}, \mathrm{s}, \mathrm{H}-18), \delta_{\mathrm{H}} 1.58(3 \mathrm{H}, \mathrm{s}, \mathrm{H}-19)$ and $\left.\delta_{\mathrm{H}} 1.44(3 \mathrm{H}, \mathrm{s}, \mathrm{H}-20)\right]$, a pair of doublet doublets at $\delta_{\mathrm{H}} 1.80,2.71,2.73$ and $3.32(\mathrm{~m}, 1 \mathrm{H}$ each) corresponding to two methylene groups, one methine group at $\delta_{\mathrm{H}} 4.18(1 \mathrm{H}, \mathrm{m}, \mathrm{H}-16)$ together with one methoxyl at $\delta_{\mathrm{H}}$ group 3.87 $(3 \mathrm{H}, \mathrm{s}, \mathrm{OMe}-12)$, two ketone groups at $\delta_{\mathrm{C}} 214.0(\mathrm{C}-3)$ and $\delta_{\mathrm{C}} 183.6(\mathrm{C}-7)$, and six aromatic C-atom signals at $\delta_{C} 109.5,118.7,132.9,139.3,140.3$ and 142.4. These data, together with other spectroscopic characteristics, suggested that 8 was a diterpenoid [10]. ${ }^{1} \mathrm{H}-{ }^{1} \mathrm{H}$ COSY correlations were observed from: $\mathrm{H}-1\left(\delta_{\mathrm{H}} 1.80\right.$ and $\left.\delta_{\mathrm{H}} 3.32\right)$ to $\mathrm{H}-2\left(\delta_{\mathrm{H}} 2.71\right.$ and $\left.\delta_{\mathrm{H}} 2.73\right)$; and $\mathrm{H}-17\left(\delta_{\mathrm{H}} 1.28\right)$ through $\mathrm{H}-16\left(\delta_{\mathrm{H}}\right.$ 4.18) to $\mathrm{H}-15\left(\delta_{\mathrm{H}} 2.83\right.$ and $\left.\delta_{\mathrm{H}} 2.91\right)$, in combination with HMBC correlations (Figure 2) between: H-20 $\left(\delta_{\mathrm{H}} 1.44\right)$ to $\mathrm{C}-1\left(\delta_{\mathrm{C}} 26.9\right), \mathrm{C}-5\left(\delta_{\mathrm{C}} 140.3\right), \mathrm{C}-9\left(\delta_{\mathrm{C}} 139.3\right)$, and C-10 $\left(\delta_{\mathrm{C}} 40.6\right) ; \mathrm{H}-15\left(\delta_{\mathrm{H}} 2.83\right.$ and $\left.\delta_{\mathrm{H}} 2.91\right)$ to $\mathrm{C}-12\left(\delta_{\mathrm{C}} 152.6\right), \mathrm{C}-13\left(\delta_{\mathrm{C}} 118.7\right), \mathrm{C}-14\left(\delta_{\mathrm{C}} 155.2\right), \mathrm{C}-16\left(\delta_{\mathrm{C}} 67.8\right)$ and $\mathrm{C}-17\left(\delta_{\mathrm{C}} 23.8\right)$, which suggested that the oxygenated substituent was placed at the $\mathrm{C}-16$ position $\left(-\mathrm{CH}_{2} \mathrm{CH}(\mathrm{OH}) \mathrm{CH}\right)_{3}$, and the side chain of 8 is not an isopropyl but rather a 2-hudroxy-n-propyl group $\left(\mathrm{CH}_{3}-17\right.$ shifted to C-16 from C-15); OH-6 $\left(\delta_{\mathrm{H}} 6.86\right)$ to $\mathrm{C}-6\left(\delta_{\mathrm{C}} 142.4\right)$ and $\mathrm{C}-7\left(\delta_{\mathrm{C}} 183.6\right) ; \mathrm{OH}-11\left(\delta_{\mathrm{H}} 5.97\right)$ to $\mathrm{C}-11$ $\left(\delta_{\mathrm{C}} 132.9\right)$; OH-14 $\left(\delta_{\mathrm{H}} 12.56\right)$ to $\mathrm{C}-8\left(\delta_{\mathrm{C}} 109.5\right), \mathrm{C}-13\left(\delta_{\mathrm{C}} 118.7\right)$ and $\mathrm{C}-14\left(\delta_{\mathrm{C}} 155.2\right) ; \mathrm{The}{ }^{1} \mathrm{H},{ }^{13} \mathrm{C}$ long-range correlations between $\mathrm{H}-21\left(\delta_{\mathrm{H}} 3.87\right)$ to $\mathrm{C}-12\left(\delta_{\mathrm{C}} 152.6\right)$, therefore, compound 8 possesses an abeo-abietane diterpenoid framework with an $\mathrm{OCH}_{3}$ group on $\mathrm{C}-12$. Thus, the structure of 8 was elucidated as 12-methoxy-6,11,14,16-tetrahydroxy-17(15 $\rightarrow 16)$-abeo-5,8,11,13- abietatetraen-3,7-dione. (The NMR spectra of compound 8 are listed in the Supplementary Materials).

The seven known compounds were identified as mandarone A (1) [11], taxusabietane A (2) [12], 12-O-demethylcrypto-japonol (3) [13], cryptojaponol (4) [14], 11,14-dihydroxy-8,11,13-abietatrien-7-one (5) [15], fortunin E (6) [16], fortunin F (7) [16], by comparison of their spectra with those reported in the literature.

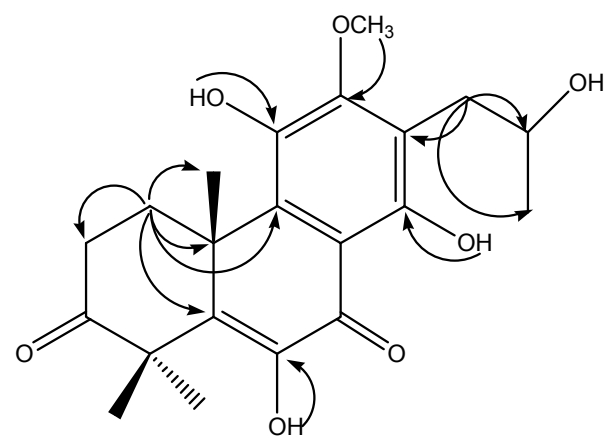

Figure 2. Key HMBC correlations for compound 8. 
Table 1. NMR spectroscopic data for compound 8 in $\mathrm{CDCl}_{3}$.

\begin{tabular}{|c|c|c|c|}
\hline NO & $\delta_{\mathrm{H}}(J$ in $\mathrm{Hz})$ & $\delta_{C}$ & НМВС \\
\hline 1 & $\begin{array}{l}1.80, \mathrm{~m}, \alpha \\
3.32, \mathrm{~m}, \beta\end{array}$ & $26.9, \mathrm{CH}_{2}$ & $C-2, C-3, C-10, C-20$ \\
\hline 2 & $\begin{array}{l}2.71, \mathrm{~m}, \alpha \\
2.73, \mathrm{~m}, \beta\end{array}$ & $33.2, \mathrm{CH}_{2}$ & $C-1, C-3, C-4, C-10$ \\
\hline 3 & & 214.0, qC & \\
\hline 4 & & $48.8, \mathrm{qC}$ & \\
\hline 5 & & $140.3, \mathrm{qC}$ & \\
\hline 6 & & $142.4, \mathrm{qC}$ & \\
\hline 7 & & $183.6, \mathrm{qC}$ & \\
\hline 8 & & $109.5, \mathrm{qC}$ & \\
\hline 9 & & $139.3, \mathrm{qC}$ & \\
\hline 10 & & $40.6, \mathrm{qC}$ & \\
\hline 11 & & $132.9, \mathrm{qC}$ & \\
\hline 12 & & $152.6, \mathrm{qC}$ & \\
\hline 13 & & $118.7, \mathrm{qC}$ & \\
\hline 14 & & $155.2, \mathrm{qC}$ & \\
\hline 15 & $\begin{array}{l}2.91, \mathrm{dd}(13.8,4.0)^{\mathrm{a}} \\
2.83, \mathrm{dd}(13.7,8.3)^{\mathrm{a}}\end{array}$ & $32.9, \mathrm{CH}_{2}$ & C-12, C-13, C-14, C-16, C-17 \\
\hline 16 & $4.18, \mathrm{~m}$ & $67.8, \mathrm{CH}$ & C-15, C-17 \\
\hline 17 & $1.28, \mathrm{~d}(6.2)$ & $23.8, \mathrm{CH}_{3}$ & C-15, C-16 \\
\hline 18 & $1.58, \mathrm{~s}$ & $21.0, \mathrm{CH}_{3}$ & $C-3, C-4, C-5, C-19$ \\
\hline 19 & $1.53, \mathrm{~s}$ & $24.3, \mathrm{CH}_{3}$ & C-3, C-4, C-5, C-18 \\
\hline 20 & $1.44, \mathrm{~s}$ & $20.0, \mathrm{CH}_{3}$ & $C-1, C-5, C-9, C-10$ \\
\hline $21-\mathrm{OCH}_{3}$ & $3.87, \mathrm{~s}$ & $61.7, \mathrm{OCH}_{3}$ & C-12 \\
\hline
\end{tabular}

a Assignments may be reversed.

To investigate their cytotoxic activities, these compounds were evaluated using an MTT cytotoxicity assay against human myeloid leukemia (HL-60), hepatocellular carcinoma (SMMC-7721), lung cancer (A-549) and breast cancer (MCF-7) cell lines. The $\mathrm{IC}_{50}$ values of all eight compounds against the indicated cancer cells are summarized in Table 2. Compound 6 and $\mathbf{8}$ exhibited the strongest cytotoxicity to all cells, as its range of $\mathrm{IC}_{50}$ values was $1.8-5.0 \mu \mathrm{M}$. Additionally, A-549 was the most sensitive cell line to these types of compounds among all tested cancer cells because the $\mathrm{IC}_{50}$ values of all compounds against A-549 cells were close to $10 \mu \mathrm{M}$. Furthermore, the cytotoxicities of all the isolated compounds were comparable to the chemotherapeutic drug cisplatin [17], which suggests that these compounds might have promising potential to be anticancer agents.

Table 2. Cytotoxic activities of compounds 1-8 isolated from C. kiangsiense (IC 50 in $\mu \mathrm{M})$.

\begin{tabular}{ccccc}
\hline Compounds & HL-60 & SMMC-7721 & A-549 & MCF-7 \\
\hline $\mathbf{1}$ & $12.5 \pm 1.2$ & $13.6 \pm 0.8$ & $7.4 \pm 1.1$ & $27.7 \pm 2.2$ \\
$\mathbf{2}$ & $18.6 \pm 1.8$ & $15.9 \pm 1.6$ & $10.2 \pm 1.2$ & $15.4 \pm 2.7$ \\
$\mathbf{3}$ & $23.5 \pm 2.0$ & $33.0 \pm 2.4$ & $10.4 \pm 1.3$ & $19.2 \pm 1.8$ \\
$\mathbf{4}$ & $9.9 \pm 0.9$ & $6.7 \pm 1.0$ & $8.7 \pm 0.8$ & $10.0 \pm 0.8$ \\
$\mathbf{5}$ & $15.5 \pm 1.9$ & $15.7 \pm 1.6$ & $11.8 \pm 2.4$ & $22.4 \pm 2.9$ \\
$\mathbf{6}$ & $4.8 \pm 0.5$ & $3.8 \pm 0.9$ & $2.7 \pm 0.7$ & $5.0 \pm 1.0$ \\
$\mathbf{7}$ & $15.7 \pm 1.8$ & $5.8 \pm 0.8$ & $7.9 \pm 0.7$ & $19.2 \pm 1.4$ \\
$\mathbf{8}$ & $1.8 \pm 0.3$ & $4.9 \pm 0.7$ & $2.5 \pm 0.7$ & $3.1 \pm 0.5$ \\
Cisplatin & $4.2 \pm 0.5$ & $5.9 \pm 0.9$ & $9.8 \pm 1.1$ & $11.3 \pm 1.0$ \\
\hline
\end{tabular}

Results are expressed as means of $\mathrm{IC}_{50}$ values (the concentration that reduced cell growth by $50 \%$ ) in $\mu \mathrm{M}$, and data were obtained from triplicate experiments. 


\section{Materials and Methods}

\subsection{General Experimental Procedures}

Melting points were measured using a XT-4 micro melting point apparatus (Beijing, China). Optical rotations were determined at $25^{\circ} \mathrm{C}$ on a JASCO (Tokyo, Japan) P2000 polarimeter. UV data were measured using a Shimadzu UV-2550 spectrophotometer (Shimadzu, Kyoto, Japan). IR spectra were recorded on a Nicolet 380 FT-IR spectrophotometer (Thermo Fisher Scientific, Waltham, MA, USA). NMR spectra were recorded on a Bruker Avance III 500 spectrometer (Bruker, Bremen, Germany), using TMS as internal standard, Chemical shifts are reported as $\delta$ values and the coupling constants $(J)$ are in Hz. HRESIMS data were obtained on a Agilent 6210 TOF-MS mass spectrometer; HPLC (Amersham Biosciences, GE Healthcare Life Science, Santa Clara, CA, USA), Waters 1525 semi-preparative HPLC system (Waters Co. Ltd., Milford, MA, USA) coupled with a Waters 2996 photodiode array detector. A Kromasil C18 preparative HPLC column $(250 \times 10 \mathrm{~mm}, 5 \mu \mathrm{m})$ was used; Column chromatography was carried out on silica gel (Qing Dao Hai Yang Chemical Group Co., Qingdao, China; 200-300 mesh) and Sephadex LH-20 (Amersham Biosciences). TLC analyses were carried out on silica gel $60 \mathrm{~F}_{254}$ (Merck, Darmstadt, Germany) and RP-18 $\mathrm{F}_{254 \mathrm{~s}}$ (Merck) plates. Compounds were detected by UV and $30 \% \mathrm{H}_{2} \mathrm{SO}_{4}$ spraying reagent followed by heating at $105^{\circ} \mathrm{C}$ for $1-2 \mathrm{~min}$.

\subsection{Plant Material}

The stems of C. kiangsiense were collected on the Wugong Mountain of Pingxiang City, Jiangxi Province, China, in September 2010, and identified by Chunhui Dai in Zhejiang Academy of Traditional Chinese Medicine. A voucher specimen (No. 201007) has been deposited in the Key Laboratory for Genetic Improvement and Quality Control of Medical Plants of Zhejiang Province.

\subsection{Extraction and Isolation}

The air-dried powder of the stems $(7.6 \mathrm{~kg})$ of C. kiangsiense was extracted by $90 \%$ ethanol $(30 \mathrm{~L} \times 3)$ at $65{ }^{\circ} \mathrm{C}$. The solvents were combined and evaporated to dryness under vacuum at $50{ }^{\circ} \mathrm{C}$ to afford a gummy residue $(110 \mathrm{~g})$. This residue was suspended in $\mathrm{H}_{2} \mathrm{O}(1000 \mathrm{~mL})$ and partitioned with petroleum ether $(1000 \mathrm{~mL} \times 3,19 \mathrm{~g})$, ethyl acetate (EtOAc) $(1000 \mathrm{~mL} \times 3,32 \mathrm{~g})$, and $n$-BuOH $(1000 \mathrm{~mL} \times 3$, $9 \mathrm{~g})$, successively. The EtOAc fraction (19 g) was subjected to silica-gel column chromatography (CC) with a step gradient elution of petroleum ether-EtOAc (20:1 to 1:4, v/v) to afford 8 fractions (Fr.1-Fr.8). Fr.2 was repeatedly separated by silica gel column chromatography eluted with a petroleum ether-EtOAc gradient (20:1 to 4:1, v/v) to give compound $1(13 \mathrm{mg})$, compound 3 (7 $\mathrm{mg})$ and a fraction that was a mixture of three compounds. Further chromatographic purification on Sephadex LH-20 CC with a methanol afforded compound $2(9 \mathrm{mg})$, compound 8 (9 mg) and compound 4 (10 mg). The separation of Fr.3 on silica gel eluted with EtOAc:petroleum ether (10:1 to 2:1, v/v) afforded a mixture (40 mg) of compounds 5 (7 mg), 6 (7 mg) and 7 (16 mg), which was separated by prep-HPLC using an acetonitrile-water mixture $(30: 70 \mathrm{v} / \mathrm{v})$.

Compound 8: colorless crystals; m.p. $284-285^{\circ} \mathrm{C} ;[\alpha]_{D}^{25}+15.7^{\circ}(c 0.1, \mathrm{MeOH}) ; \mathrm{UV} \lambda_{\max }: 238,285$, 336, $381 \mathrm{~nm}$; IR (KBr) $v_{\max }: 3405,1715,1660,1605,1581,1500,1457,1382,1331 \mathrm{~cm}^{-1} ;{ }^{1} \mathrm{H}-$ and ${ }^{13} \mathrm{C}-\mathrm{NMR}$ $\left(\mathrm{CDCl}_{3}\right)$ spectroscopic data, see Table 1 ; HRESIMS (negative ion mode) $\mathrm{m} / z$ 389.1597 [M $\left.-\mathrm{H}\right]^{-}$(calcd. for $\mathrm{C}_{21} \mathrm{H}_{25} \mathrm{O}_{7}^{-}$, 389.1599).

\subsection{Anti-Proliferative Activity}

The percentage of growth inhibition was determined using a MTT colorimetric technique to measure four viable cells (HL-60 human myeloid leukemia, SMMC-7721 hepatocellular carcinoma, A-549 lung cancer and MCF-7 breast cancer) with minor modification [18,19]. A total of 5000-10,000 exponential phase cells per well were seeded onto a 96-well plate for $24 \mathrm{~h}$, Each tumor cell line was exposed to a test compound at concentrations of $0.0624,0.32,1.6,8$, and $40 \mu \mathrm{M}$ in DMSO in triplicate for $72 \mathrm{~h}$, with cisplatin as the positive control. Briefly, $100 \mu \mathrm{L}$ of a MTT working solution $(1 \mathrm{mg} / \mathrm{mL})$ 
was added into each well and incubated at $37^{\circ} \mathrm{C}$ for $4 \mathrm{~h}$ and then the medium was removed. The converted dye formazan was solubilized with $150 \mu \mathrm{L}$ acidic isopropanol $(0.04 \mathrm{M} \mathrm{HCl}$ in absolute isopropanol) and each concentration was tested in triplicate. The absorbance was then measured at a wavelength of $570 \mathrm{~nm}$ using a microplate reader (Multiskan Spectrum, Thermo Electron Corporation, Vantaa, Finland). The dose resulting in $50 \%$ inhibition of cell growth $\left(\mathrm{IC}_{50}\right)$ was calculated by the Reed and Muench method.

\section{Conclusions}

In the present study, a new abeo-abietane diterpenoid, 12-methoxy-6,11,14,16-tetrahydroxy$17(15 \rightarrow 16)$-abeo-5,8,11,13-abietatetraen-3,7-dione $(8)$ was isolated from $C$. kiangsiense by chromatographic separation of a $90 \% \mathrm{EtOH}$ extract of its stems. In addition, 7 known compounds (1-7) were also obtained. The structures of compounds 1-8 were determined by spectroscopical data interpretation. The isolated compounds were subsequently evaluated for cytotoxic activities against HL-60 human myeloid leukemia, SMMC-7721 hepatocellular carcinoma, A-549 lung cancer and MCF-7 breast cancer cells, respectively. Compounds 4, 6 and 8 exhibited the strongest cytotoxicity to all cells. Additionally, A-549 was the most sensitive cell line to these types of compounds among all tested cancer cells. Furthermore, the cytotoxicities of the isolated compounds were comparable to the chemotherapeutic drug cisplatin, which suggests that $C$. kiangsiense and its constituents could be useful sources of candidates for the development of anticancer medicines.

Supplementary Materials: Supplementary materials can be accessed at: http:/ /www.mdpi.com/1420-3049/21/ $1 / 86 /$ s1.

Acknowledgments: Financial support from the Project of Zhejiang Provincial Natural Science Foundation (LQ14C010003, LQ13C200007), the Research Foundation of Education Bureau of Zhejiang Province (Y201327898), the Hangzhou Science and Technology Development Plan (20140432B06) are gratefully acknowledged.

Author Contributions: Mingfeng Xu and Lu'e Shi planned the work; Shengjia Wang, Ouya Jia and Qin Zhu performed the experiments; Shengjia Wang and Ouya Jia analyzed the data; Mingfeng Xu and Qin Zhu wrote the paper.

Conflicts of Interest: The authors declare no conflict of interest.

\section{References}

1. Gazim, Z.C.; Rodrigues, F.; Amorin, A.C.; de Rezende, C.M.; Sokovic, M.; Tesevic, V.; Vuckovic, I.; Krstic, G.; Cortez, L.E.; Colauto, N.B.; et al. New natural diterpene-type abietane from Tetradenia riparia essential oil with cytotoxic and antioxidant activities. Molecules 2013, 19, 514-524. [CrossRef] [PubMed]

2. Yue, J.R.; Feng, D.Q.; Xu, Y.K. A new triterpenoid bearing octacosanoate from the stems and roots of Clerodendrum philippinum var. simplex (Verbenaceae). Nat. Prod. Res. 2015, 29, 1228-1234. [CrossRef] [PubMed]

3. Bharitkar, Y.P.; Hazra, A.; Shah, S.; Saha, S.; Matoori, A.K.; Mondal, N.B. New flavonoid glycosides and other chemical constituents from Clerodendrum phlomidis leaves: Isolation and characterisation. Nat. Prod. Res. 2015, 29, 1850-1856. [CrossRef] [PubMed]

4. $\quad$ Lee, W.S.; Kim, J.R.; Han, J.M.; Jang, K.C.; Sok, D.E.; Jeong, T.S. Antioxidant activities of abietane diterpenoids isolated from Torreya nucifera leaves. J. Agric. Food Chem. 2006, 54, 5369-5374. [CrossRef] [PubMed]

5. Liu, Q.; Hu, H.J.; Li, P.F.; Yang, Y.B.; Wu, L.H.; Chou, G.X.; Wang, Z.T. Diterpenoids and phenylethanoid glycosides from the roots of Clerodendrum bungei and their inhibitory effects against angiotensin converting enzyme and alpha-glucosidase. Phytochemistry 2014, 103, 196-202. [CrossRef] [PubMed]

6. Panthong, A.; Kanjanapothi, D.; Taesotikul, T.; Wongcome, T.; Reutrakul, V. Anti-inflammatory and antipyretic properties of Clerodendrum petasites S. Moore. J. Ethnopharmacol. 2003, 85, 151-156. [CrossRef]

7. Patel, J.J.; Acharya, S.R.; Acharya, N.S. Clerodendrum serratum (L.) Moon-A review on traditional uses, phytochemistry and pharmacological activities. J. Ethnopharmacol. 2014, 154, 268-285. [CrossRef] [PubMed]

8. Waliullah, T.M.; Yeasmin, A.M.; Alam, A.; Islam, W.; Hassan, P. In vitro antimicrobial study for biological evaluation of Clerodendrum infortunatum Linn. Recent Pat. Anti-Infect. Drug Discov. 2015, 10, 98-104. [CrossRef] 
9. Xu, R.L.; Wang, R.; Ding, L.; Shi, Y.P. New cytotoxic steroids from the leaves of Clerodendrum trichotomum. Steroids 2013, 78, 711-716. [CrossRef] [PubMed]

10. Xie, W.D.; Li, X.; Zhao, J.H.; Liu, Y.H.; Row, K.H. Abietane diterpenoids from Isodon inflexus. Phytochemistry 2012, 81, 153-158. [CrossRef] [PubMed]

11. Inaba, Y.; Hasuda, T.; Hitotsuyanagi, Y.; Aoyagi, Y.; Fujikawa, N.; Onozaki, A.; Watanabe, A.; Kinoshita, T.; Takeya, K. Abietane diterpenoids and a sesquiterpene pyridine alkaloid from Euonymus lutchuensis. J. Nat. Prod. 2013, 76, 1085-1090. [CrossRef] [PubMed]

12. Yang, S.J.; Fang, J.M.; Cheng, Y.S. Diterpenes from Taxus mairei. Phytochemistry 1998, 49, 2037-2043. [CrossRef]

13. Rodriguez, B. Structural and spectral assignment by two-dimensional NMR of two new derivatives of the abietane diterpenoid taxodione. Magn. Reson. Chem. 2005, 43, 97-99. [CrossRef] [PubMed]

14. Fronza, M.; Murillo, R.; Slusarczyk, S.; Adams, M.; Hamburger, M.; Heinzmann, B.; Laufer, S.; Merfort, I. In vitro cytotoxic activity of abietane diterpenes from Peltodon longipes as well as Salvia miltiorrhiza and Salvia sahendica. Bioorg. Med. Chem. 2011, 19, 4876-4881. [CrossRef] [PubMed]

15. Min, Z.D.; Jiang, H.; Liang, J.Y. Studies on the taxane diterpenes of the heartwood from Taxus mairei. Yao Xue Хиe Bao 1989, 24, 673-677. [PubMed]

16. Yao, S.; Tang, C.P.; Ke, C.Q.; Ye, Y. Abietane diterpenoids from the bark of Cryptomeria fortunei. J. Nat. Prod. 2008, 71, 1242-1246. [CrossRef] [PubMed]

17. Zhang, X.D.; Ni, W.; Yan, H.; Li, G.T.; Zhong, H.M.; Li, Y.; Liu, H.Y. Daphnane-type diterpenoid glucosides and further constituents of Euphorbia pilosa. Chem. Biodivers. 2014, 11, 760-766. [CrossRef] [PubMed]

18. Liang, Z.; Zhang, T.; Zhang, X.; Zhang, J.; Zhao, C. An alkaloid and a steroid from the endophytic fungus Aspergillus fumigatus. Molecules 2015, 20, 1424-1433. [CrossRef] [PubMed]

19. Caamal-Fuentes, E.E.; Peraza-Sanchez, S.R.; Torres-Tapia, L.W.; Moo-Puc, R.E. Isolation and identification of cytotoxic compounds from Aeschynomene fascicularis, a Mayan medicinal plant. Molecules 2015, 20, 13563-13574. [CrossRef] [PubMed]

Sample Availability: Not available.

(C) 2016 by the authors; licensee MDPI, Basel, Switzerland. This article is an open access article distributed under the terms and conditions of the Creative Commons by Attribution (CC-BY) license (http:/ / creativecommons.org/licenses/by/4.0/). 